2016 - Volume: 17 Number: 1

Page: 209 - 219

DOI : $10.18038 /$ btda. 11251

Received: 29 February 2016

Revised: 11 March 2016 Accepted: 04 April 2016

\title{
DETERMINATION OF CORRELATION BETWEEN SPECIFIC ENERGY CONSUMPTION AND VIBRATION OF A RAW MILL IN CEMENT INDUSTRY
}

\author{
Adem ATMACA ${ }^{1, *}$, Nihat ATMACA ${ }^{2}$ \\ ${ }^{1}$ Energy Systems Engineering, Faculty of Engineering, University of Gaziantep, 27310, Turkey \\ ${ }^{2}$ Vocational School of Technical Sciences, University of Gaziantep, 27310, Turkey
}

\begin{abstract}
In cement industry about $110 \mathrm{kWh}$ of electrical energy is consumed to produce one ton of cement and about $26 \%$ of the total electrical power is used during farine production. In this study, certain measures are implemented in an existing raw mill in a cement factory and the specific energy consumption of the unit is calculated to be $25.52 \mathrm{kWh} / \mathrm{ton}$ farine. The effects of ball charge rate, moisture content and size of feeding materials on vibration of main driving motors are investigated. The data collected over a 12-month period indicate that vibration directly related to the specific energy consumption (SEC) of the unit. The vibration on the motors of the raw mill is decreased by about $12 \%$ as the moisture content and size of the raw materials decreased by half. By this way, specific energy consumption of the unit decreased to $25.19 \mathrm{kWh} / \mathrm{ton}$ farine. Keeping the vibration values on the main driving motors less than $4 \mathrm{~mm} / \mathrm{s}$ by periodical maintenance, the specific electrical energy consumption of the mill has reduced by $2.16 \%$ to $24.97 \mathrm{kWh} /$ ton farine which corresponds to a saving of $0.55 \mathrm{kWh}$ per ton of farine production.
\end{abstract}

Keywords: Cement, Raw mill, Vibration, Energy, Grinding

\section{ÇIMMENTO ENDÜSTRISSINDE FARİN DEĞİRMENİ ÖZGÜL ENERJi TÜKETIMII VE TITTREŞIM DEĞERLERİ ARASINDAKİ İLIŞKİNIN BELİRLENMESİ}

\begin{abstract}
ÖZET
Çimento endüstrisinde 1 ton çimento üretimi için yaklaşı $110 \mathrm{kWh}$ elektrik enerjisi tüketilmektedir ve toplam elektrik enerjisinin yaklaşı \%26'sı farin üretimi sırasında harcanmaktadır. Bu çalışmamızda bir çimento fabrikasında çalıştırılmakta olan farin değirmeninden belirli ölçümler alınmış ve ünitenin özgül enerji tüketim değeri 25,52 kWh/ton farin olarak hesaplanmıştır. Bilye doluluk oranı, malzeme nem miktarı ve üniteye beslenen hammadde ebatlarının ana tahrik motorları üzerindeki titreşim değerlerine olan etkisi incelenmiştir. 12 ay boyunca düzenli olarak toplanan veriler, değirmen titreşim değerlerinin ünitenin özgül enerji tüketim (ÖET) değerlerini doğrudan etkilediğini ortaya çıkarmıştır. Hammaddenin içerdiği nem oranının yarıya düşürülmesiyle ana tahrik motorları üzerindeki titreşim değerlerinin yaklaşık \%12 oranında azaldığı tespit edilmiştir. Bu sayede, ünitenin özgül enerji tüketimi $25,19 \mathrm{kWh} /$ ton farin değerlerine düşürülmüștür. Düzenli bakımla ana tahrik motorlarındaki titreşim değerlerinin $4 \mathrm{~mm} / \mathrm{s}$ değerinin altında tutulmasıyla, değirmenin özgül enerji tüketim değeri $\% 2,16$ düşerek, 1 ton farin için yaklaşık $0,55 \mathrm{kWh}$ 'lik bir enerji tasarrufunu sağlanmış ve değirmenin enerji tüketimi 24,97 $\mathrm{kWh} /$ ton farin değerine düşürülmüştür.
\end{abstract}

Anahtar Kelimeler: Çimento, Farin değirmeni, Titreşim, Enerji, Öğütme

\section{INTRODUCTION}

Farine which is the semi product of clinker is an important material which is produced by raw mills in cement industry. About one third of the electrical power is consumed during the farine production in a conventional cement factory. Improving machine design and choosing optimal operating conditions could possibly lead to the development of new approaches toward energy saving in cement production [1]. About 1.6 billion ton cement is produced per year in the World in 2011. About 2\% of the electricity produced in the whole world is used during the grinding process of raw materials [2]. While total electrical energy consumption for cement production is about $100 \mathrm{kWh} / \mathrm{ton}$ of cement, roughly two

*Corresponding Author: aatmaca@gantep.edu.tr 
thirds are used for particle size reduction [3]. About 65\% of the total electrical energy used in a cement plant is utilized for the grinding of coal, raw materials and clinker Figure 1 [4].

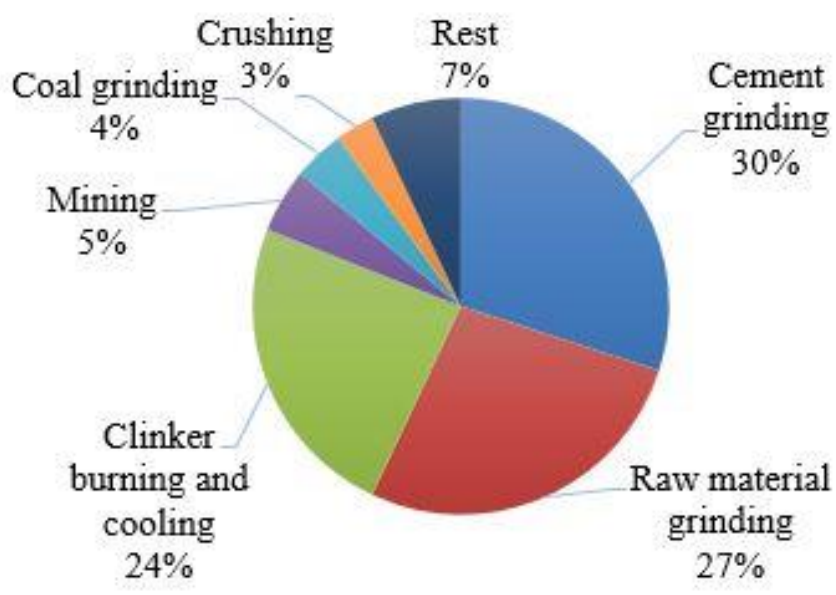

Figure 1. The use of electrical energy in cement production

While producing large amounts of cement, the sector is one of the worst pollutant industries in the World [5]. Primary physical energy intensity for cement production has dropped by $30 \%$, from $7.9 \mathrm{GJ} /$ ton to $5.6 \mathrm{GJ} /$ ton since 1970 [6]. However at the same time the production of cement increased from 570 million tons to 1.6 billion tons per year. As a result, about $5 \%$ of global carbon dioxide emissions originate from cement production. About half of this is due to calcinations and the remaining half is due to combustion processes. In a cement plant, using energy efficiently during grinding process will lower the production costs considerably. That will also lead to lower the emission rates [7]. A wide range of options exists to reduce $\mathrm{CO}_{2}$ emissions [8], and almost all of them are based on increasing energy efficiency in various processes in industry. At the first part of the literature survey, it is seen that there are some studies covering the energy consumption of different units in cement industry.

Schuer et al. [9] studied energy consumption data and focused on the energy saving methods for German cement industry considering electrical energy saving methods and thermal energy saving methods. Worell et al. [6] dealt with energy analysis in the U.S. cement industry for the years 1970 and 1997. The study indicates that for a dry type cement production process, the carbon dioxide emission intensity for kiln feed preparation process is about $5.4 \mathrm{~kg} \mathrm{CO}_{2}$ per ton cement produced. Utlu et al. [10] studied energy and exergy efficiencies of a raw mill for analysis and improvement of the plant.

There are many studies about grinding process in cement industry. Sögüt et al. [11] calculated first-law (energy) and second-law (exergy) efficiencies of a raw mill by varying dead state temperatures between $-18^{\circ} \mathrm{C}$ and $41^{\circ} \mathrm{C}$.

At the second stage of the literature survey, it should be seen that the experimental analysis are generally carried out on laboratory scale ball mills. Behera et al. [12] have picked up vibration signals by using accelerometers mounted directly on the mill shaft of a ninety centimeter diameter mill. The time domain signals were transformed to frequency domain by using fast Fourier transform. The grinding behavior under dry as well as wet grinding conditions was analyzed by following the variations in the vibration signature as a function of speed of the mill, volumetric filling, powder loading, and time of grinding.

Kolacz [13] investigated the influence of the mill load (powder filling) on a dry fine grinding circuit. To improve the circuit performance at industrial scale, alternative ways of mill load measurement were investigated. He used a piezoelectric strain transducer to detect strain changes in the mill shell during 
mill rotation and evaluated the weight of the mill charge and controlled the powder filling to obtain an optimal level. By measuring mechanical vibration with the transducer, additional useful information has been obtained about the behavior of the cataracting and cascading balls inside the mill shell.

Gugel and Moon [14] studied mill load variations by using vibration sensors. The sensors were mounted directly on the mill shell. They developed the neural net soft-sensor model and predict the filling level of the dry ball mill.

Zeng and Forssberg [15] studied the mechanical vibration of tumbling mills using accelerometers. They used several grinding parameters to see the variations in vibration signals. The technique that they used to interpret vibration data is difficult and it is not possible to quantify the difference in signals by direct inspection.

Huang et al. [16], were analyzed the relationship between the filling level and the position of the maximum vibration point on the mill shell. They detected that when the filling level increases the position of the maximum vibration point on the mill shell moves to a lower angular position.

There are many studies about raw mills in cement industry. Some of the studies focus on increasing the efficiency of the unit and some of them emphasize the effects of some different parameters on the vibration values of the system to establish the optimal operating conditions by recording and analyzing the vibration on the unit regularly. The literature survey indicates that studies on industrial scale raw mill in cement industry under real working conditions are limited in number. In this study, the raw mill of a cement plant is considered and its specific energy consumption is investigated. Effects of ball charge rate, humidity and size of the feeding materials on vibration values of the system are studied. The effect of vibration on the main driving motors to the electricity consumption of unit is analyzed. In that way, the relation between the vibration and specific energy consumption of the whole unit is be revealed. This paper can contribute to a better understanding of raw mill operation and parameters affecting the electrical energy consumption of the unit.

\section{SYSTEM ANALYSIS}

\subsection{Description of Farine Production Process}

The most common raw materials used for farine production are limestone, chalk and clay [17]. These raw materials are extracted from a quarry near to the plant. The collected raw materials are crushed and carried to the raw mill for grinding process. Raw material preparation is an electricity-intensive production step. The materials are ground in a ball mill until the desired properties are provided. Steel balls are responsible for decreasing the size of the raw material pieces in the rotating tube. The product of raw mills are called as; farine which is the semi product of clinker. It is then fed to the rotary burner which transforms it into clinker which is the semi product of cement. After the grinding process in a cement mill, the production process completes (Figure 2). 


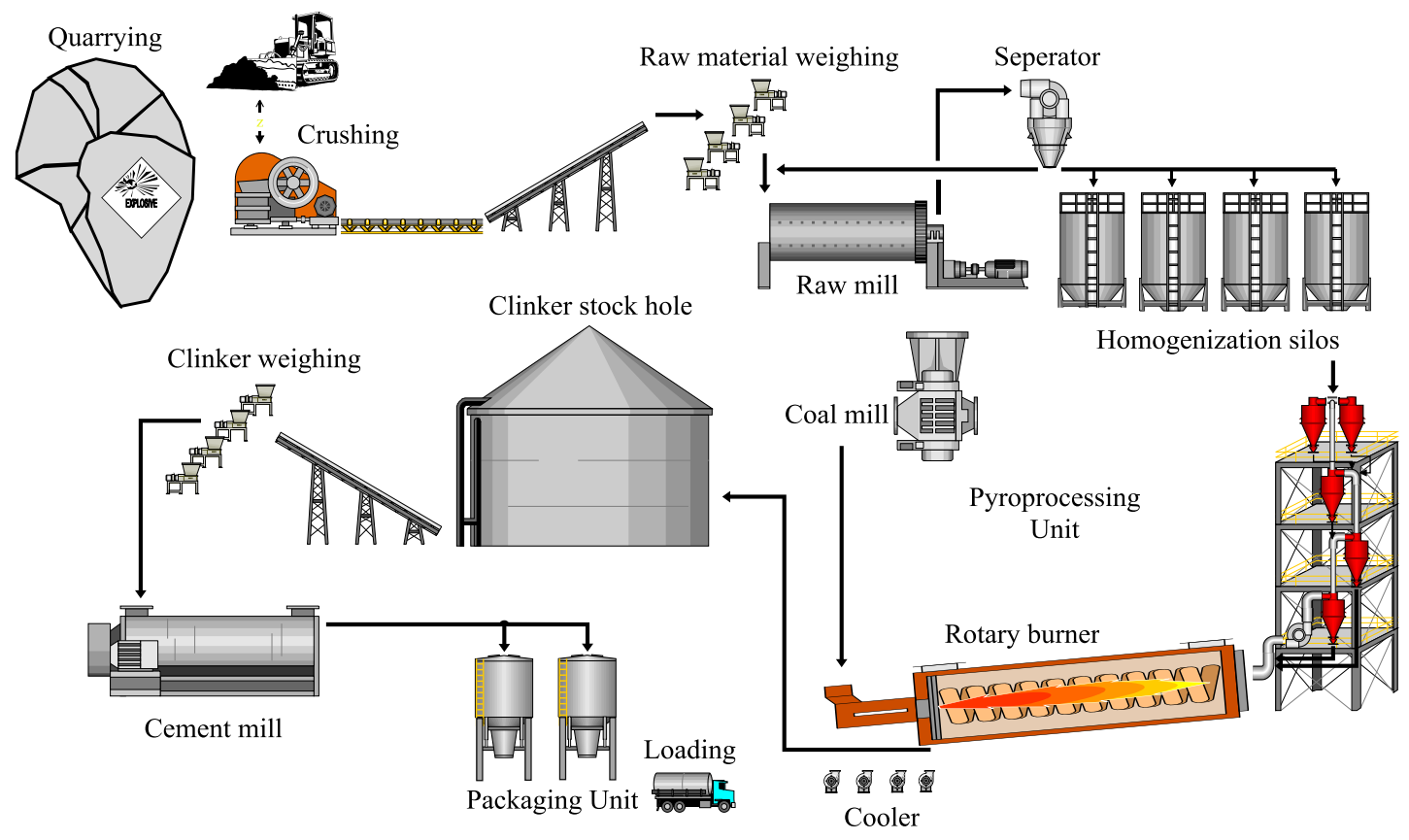

Figure 2. Cement production process

When selecting the most convenient grinding and drying process, various factors must be considered such as size, humidity and grindability of the feeding materials, ambient air conditions, mill size, and quantity of hot gas which is sucked from the rotary burner. Therefore it is not easy to accept a grinding and drying process ideal or most convenient [18].

The raw mill considered in this study is located in a cement plant located in Gaziantep, Turkey. The plant is a double chamber mill with mechanical circulation system which grinds a medium hard material at a capacity of about 102 tons/h. The mill diameter is $4000 \mathrm{~mm}$ and the grinding chamber length is $9,950 \mathrm{~mm}$ (Table 1). The bunkers contain raw materials and these materials are fed to the mill with required proportions where they are dried and ground. After that, the pulverized material is conveyed to the separator with a bucket elevator. The oversized material is conveyed back for further grinding. The amount of recirculating material designates the feed rate through the raw mill. With the help of an external air heater, 10 to $20 \%$ of moisture content can be dried. If the only external heat supply is the rotary burner, only 5 to $10 \%$ moisture content of the input materials can be dried.

Table 1. Raw mill specifications.

\begin{tabular}{ll}
\hline Model & Horizontal double chamber ball mill \\
\hline Inner diameter (mm) & 4,000 \\
Length (mm) & 9,950 \\
Rotational speed (rpm) & 15.8 \\
Ball charge capacity (tons) & 115 \\
Feeding mine granularity (mm) & $\leq 40$ \\
Moisture Content of Feed and Discharge $(\%)$ & $15-1$ \\
Fineness Residue $90 \mu \mathrm{m}(\%)$ & $12-14$ \\
Processing capacity (tons/h) & 102 \\
Total power of main driving motors $(\mathrm{kW})$ & 2000 \\
Net weight of mantle (tons) & 240 \\
\hline
\end{tabular}




\subsection{Vibration Analysis of the Raw Mill}

Collection and processing of the vibration signals are very critical during the investigation of the system. A sensitive portable SKF Microlog Vibration Analyzer device is used during the diagnosis and analysis of vibration on the main driving motors of the unit. The device has four channels and able to gather the signals over a range of $10 \mathrm{CPM}(0,16 \mathrm{~Hz})$ to $4800000 \mathrm{CPM}(80 \mathrm{kHz})$ (See Table 2). With the help of data recorder module the signals from sensors connected to the device are digitally recorded and stored as standard time waveform files (WAV). The data is collected and transferred to a computer for additional analysis. The data acquisition is governed by the SKF Aptitude Analyst programming environment which is a software development package designed specifically for instrument control and measurement. The geometry of the mill and the main driving motors where the data gathered are presented in Figure 3.

Table 2. Device specifications

\begin{tabular}{ll}
\hline Signal input & Accelerometer, velocity, displacement. \\
Measurement parameters & Acceleration, velocity, displacement. \\
Measurement types & Overall, spectrum, time waveform, cross phase, shaft centerline \\
Signal & RMS / Peak / Peak-Peak / True Peak / True Peak-Peak \\
Transducer check & Bias Voltage Integrity \\
Dynamic range & $>90 \mathrm{~dB}$ \\
Frequency range & DC to $80 \mathrm{kHz}$ \\
Bearing condition & $\mathrm{gE}$ \\
gE filters & $5 \mathrm{~Hz}$ to $100 \mathrm{~Hz}, 50 \mathrm{~Hz}$ to $1 \mathrm{kHz}, 500 \mathrm{~Hz}$ to $10 \mathrm{kHz}, 5 \mathrm{kHz}$ to $40 \mathrm{kHz}$ \\
FFT resolution & 100 to 25600 lines \\
Time block length & 256 to 65536 samples \\
Averaging & RMS, Time, Peak Hold \\
\hline
\end{tabular}

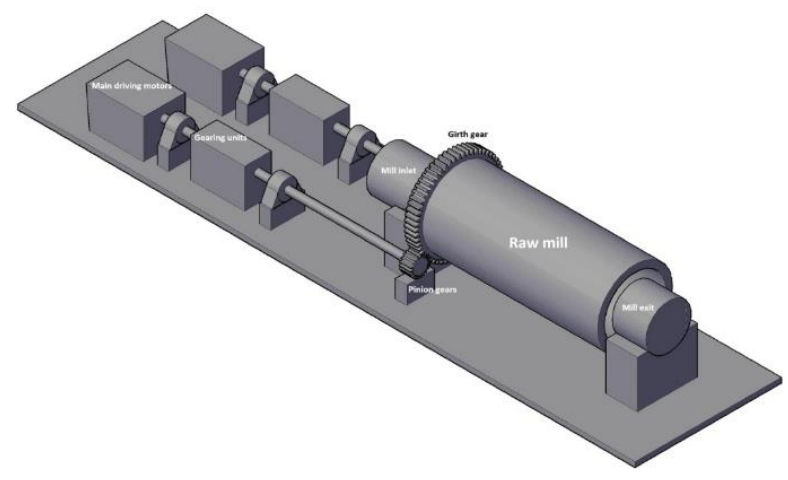

Figure 3. Raw mill unit

\subsection{Calculation of the Specific Energy Consumption of the Unit}

In cement industry, there are two main types of energy use; fuel and electricity. The raw mill here uses high amounts of electrical energy during the grinding process of feeding materials. Therefore, we calculate specific energy consumption for electricity. Electricity consumption, farine production, and the specific energy consumption of the mill under standard conditions are given on a monthly basis in Table 3. While calculating the specific energy consumption all the equipments (main drive and auxiliary motors, bucket elevator, separator, electro-filter, and system fan motors) used during the production of 
farine are taken into consideration. The raw mill system consumes an average of 1,380,939 kWh of electricity while producing 54,274 tons of farine per month. Then the specific energy consumption for electricity is determined to be, $\operatorname{SEC}=(1,380,939 \mathrm{kWh} / 54,107$ tons $)=25.52 \mathrm{kWh} /$ ton farine.

Table 3. Monthly electrical energy consumption, farine production and specific energy consumption of the raw mill*

\begin{tabular}{cccc}
\hline Months & $\begin{array}{c}\text { Total production } \\
\text { (tons) }\end{array}$ & $\begin{array}{c}\text { Electricity consumption } \\
(\mathrm{kWh})\end{array}$ & $\begin{array}{c}\text { SEC } \\
(\mathrm{kWh} / \mathrm{ton})\end{array}$ \\
\hline January & 58,652 & $1,551,345$ & 26.45 \\
February & 48,366 & $1,269,124$ & 26.24 \\
March* & 18,996 & 493,706 & 25.99 \\
April & 46,560 & $1,203,576$ & 25.85 \\
May & 59,128 & $1,506,581$ & 25.48 \\
June & 60,996 & $1,536,489$ & 25.19 \\
July & 61,233 & $1,522,252$ & 24.86 \\
August & 60,892 & $1,501,597$ & 24.66 \\
September & 59,669 & $1,486,951$ & 24.92 \\
October & 59,274 & $1,502,003$ & 25.34 \\
November & 57,966 & $1,503,043$ & 25.93 \\
December & 57,556 & $1,494,604$ & 25.97 \\
Average & 54,107 & $1,380,939$ & 25.52 \\
\hline
\end{tabular}

* Standard conditions with $8 \%$ humidity, $30 \mathrm{~mm}$ feed material size, 113 ton of ball charge rate and 101 ton/h production capacity.

**Annual maintenance month for the unit.

\section{RESULTS AND DISCUSSION}

In cement industry, it is known that the ball mills with heavy loads produce strong vibrations. The most convenient way to analyze these signals is to view them in the time domain. It indicates the deviation of amplitude with respect to time. The sine waves which are generated by the unit enable us represent the complex wave form of the mill vibration signal in the frequency domain. The relative amplitudes of these sine waves of different frequencies contain information directly related to the operating state of grinding. Thus, the time domain waveforms are transformed into frequency domain by fast Fourier transform (FFT) technique. With this analysis, it is possible to correlate the variations in the characteristics of the vibration signals to different parameters in the unit [12].

\subsection{The Effects of the Ball Charge Rate on Vibration and Specific Energy Consumption of the Unit}

By using the vibration analyzer device, the overall spectrum values with respect to ball charge rate and capacity of the mill are investigated and represented in Table 4. It is seen from the table that the vibration values of the unit increases with respect to the ball tonnage and production capacity of the mill. Each case is implemented for about one month and the electricity consumption of the unit is noted. Readings of electric meters indicate that electricity consumption is increased by increasing the ball tonnage and vibration on the main driving motors of the unit (Figure 4). 
Table 4. Overall spectrum values and monthly electricity consumption of main driving motors with respect to the capacity of the unit

\begin{tabular}{cccccccc}
\hline Cases & $\begin{array}{c}\text { Ball tonnage } \\
\text { (ton) }\end{array}$ & $\begin{array}{c}\text { Farine } \\
\text { production } \\
\text { (ton/h) }\end{array}$ & \multicolumn{2}{c}{$\begin{array}{c}\text { Vibration } \\
(\mathrm{mm} / \mathrm{s})\end{array}$} & $\begin{array}{c}\text { Electricity } \\
\text { consumption } \\
(\mathrm{kWh} / \mathrm{month})\end{array}$ & $\begin{array}{c}\text { Production } \\
\text { (tons/month) }\end{array}$ & $\begin{array}{c}\text { SEC } \\
(\mathrm{kWh} / \mathrm{kon})\end{array}$ \\
\cline { 4 - 5 } & 107 & 98 & $1^{\text {st }}$ motor & $2^{\text {nd }}$ motor & & & \\
\hline 1 & 110 & 100 & 2,319 & 1,702 & $1,451,990$ & 57,165 & 25.40 \\
$3^{*}$ & 113 & 101 & 2,912 & 2,625 & $1,482,606$ & 58,096 & 25.52 \\
4 & 115 & 104 & 3,486 & 2,942 & $1,499,980$ & 58,297 & 25.73 \\
5 & 116 & 105 & 4,792 & 3,723 & $1,509,962$ & 58,277 & 25.91 \\
6 & 121 & 109 & 5,179 & 4,276 & $1,561,360$ & 59,187 & 26.38 \\
7 & 124 & 111 & 5,623 & 4,837 & $1,596,120$ & 59,579 & 26.79 \\
\hline
\end{tabular}

* Standard conditions with $8 \%$ humidity and $30 \mathrm{~mm}$ feed material size

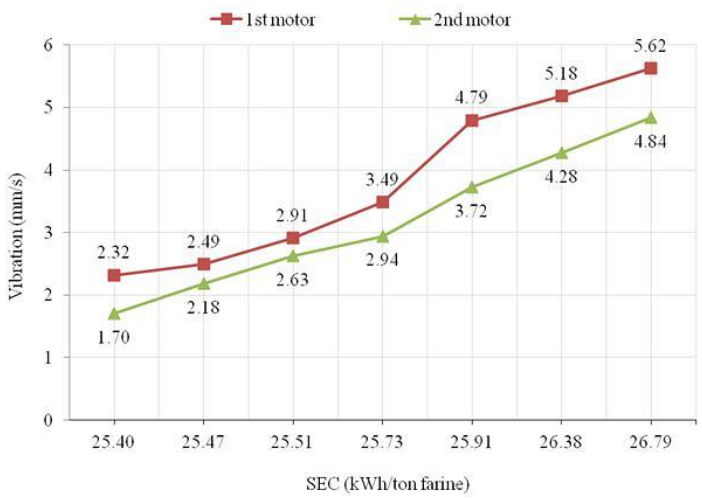

Figure 4. Relationship between vibration and SEC at different ball charge rate and production capacities of the raw mill

\subsection{The Effects of the Size and Moisture Content of Feeding Materials on Vibration and Specific Energy Consumption of the Unit}

Moisture contents of the raw materials are measured in the laboratory of the factory on a regular basis. In order to determine the moisture content of the feeding materials, a sample of each raw material entering the raw mill is weighed, heated in an oven for an appropriate period, cooled, and then reweighed in the laboratory of the factory. Moisture percentages and sizes of the feeding materials are given in Table 5. Samples from the feeding materials were obtained and the vibration data were collected at different dates to see the variation of the vibration with respect to humidity and size. It is seen that when the moisture content of the raw materials is increased or reduced, there is a corresponding change in vibration of the main driving motors, the rate of farine production and electricity consumption of the system. During the investigation, both wet and dry materials are chosen for the grinding process.

When the moisture content of the raw materials is increased to about $17 \%$, the specific energy consumption of the unit is calculated to be $26.11 \mathrm{kWh} /$ ton farine and when it is reduced to about $4 \%$ the corresponding electrical specific energy consumption value is calculated to be $25.19 \mathrm{kWh} / \mathrm{ton}$ farine (Table 6.). The vibration values on the main driving motors and the corresponding SEC values of the unit are shown in Figure 5. 
Table 5. Moisture content and sizes of feeding materials

\begin{tabular}{ccc}
\hline Feeding materials & $\begin{array}{c}\text { Moisture content }(\%) \\
\text { max. }-\min .\end{array}$ & $\begin{array}{c}\text { Sizes }(\mathrm{mm}) \\
\text { max.- min. }\end{array}$ \\
\hline Limestone & $9-4$ & $45-20$ \\
Marl & $17-7$ & $45-20$ \\
Clay & $16-6$ & $35-20$ \\
Iron ore & $14-5$ & $30-20$ \\
Bauxite & $14-5$ & $35-20$ \\
\hline
\end{tabular}

Table 6. Weekly electrical energy consumption, farine production, SEC of the raw mill and the corresponding vibration values on the main driving motors

\begin{tabular}{|c|c|c|c|c|c|c|}
\hline \multirow{2}{*}{ Cases } & \multirow{2}{*}{$\begin{array}{l}\text { Raw materials' moisture } \\
\text { contents and sizes }\end{array}$} & \multicolumn{2}{|c|}{$\begin{array}{l}\text { Vibration } \\
(\mathrm{mm} / \mathrm{s})\end{array}$} & \multirow{2}{*}{$\begin{array}{l}\text { Total production } \\
\text { (tons/week) }\end{array}$} & \multirow{2}{*}{$\begin{array}{l}\text { Electricity } \\
\text { consumption } \\
\text { (kWh/week) }\end{array}$} & \multirow{2}{*}{$\begin{array}{c}\text { SEC } \\
(\mathrm{kWh} / \text { ton })\end{array}$} \\
\hline & & $\begin{array}{c}1^{\text {st }} \\
\text { motor }\end{array}$ & $\begin{array}{c}2^{\text {nd }} \\
\text { motor }\end{array}$ & & & \\
\hline 1 & $4 / 7 \%-<20 \mathrm{~mm}$ & 2,569 & 2,302 & 15,613 & 393,291 & 25.19 \\
\hline 2 & $7 / 9 \%-<30 \mathrm{~mm}$ & 2,969 & 2,715 & 15,168 & 384,964 & 25.38 \\
\hline 3 & $9 / 11 \%-<35 \mathrm{~mm}$ & 3,366 & 2,907 & 14,863 & 380,939 & 25.63 \\
\hline 4 & $11 / 13 \%-<40 \mathrm{~mm}$ & 3,469 & 3,299 & 14,559 & 377,224 & 25.91 \\
\hline 5 & $13 / 17 \%-<45 \mathrm{~mm}$ & 4,098 & 3,791 & 14,290 & 373,112 & 26.11 \\
\hline
\end{tabular}

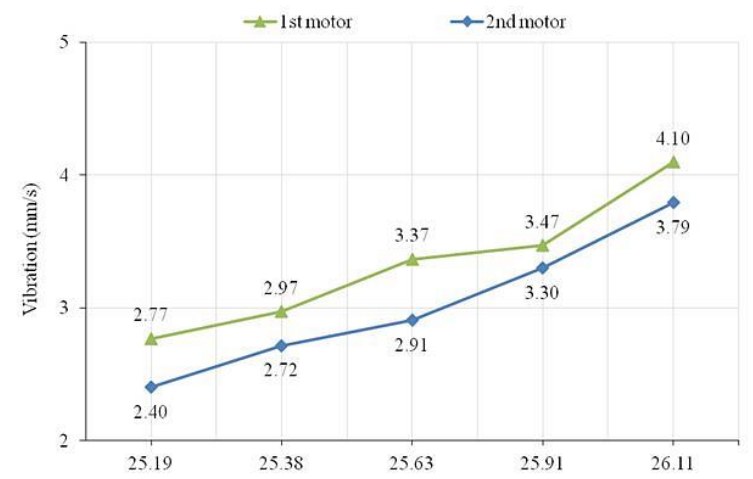

Figure 5. Relationship between vibration and SEC at different moisture contents and sizes of the feeding materials of the raw mill

\subsection{The Effects of the Periodical Maintenance of the Unit on Vibration and Specific Energy Consumption}

The system transmits power through two shafts. Each shaft has a length of about $6,450 \mathrm{~mm}$ and supported by three ball bearings between the gearing unit and pinion gears of the mill. In order to reduce the vibration values on the system, an effective lubrication is applied at all rotating parts of the unit. The connection bolts of the main driving motors, main gearing units, auxiliary motors, pinion gears and ball bearing beds are controlled and the loose sections are tightened regularly. The vibration values of the unit are compared with the values before the application of this strict periodical maintenance. The mill ball load and the production rate are kept constant during the analysis. Table 7 presents the farine production, electricity consumption, SEC of the unit for one week and vibration values at the main driving motors after the periodical maintenance of the unit. It is represented as "good conditions" for the mill. 
Atmaca and Atmaca / Anadolu Univ. J. of Sci. and Technology-A-Appl. Sci. and Eng. 17 (1) - 2016

Table 7. Comparison of the good and standard working conditions of the mill*

\begin{tabular}{cccccc}
\hline $\begin{array}{c}\text { Good } \\
\text { conditions } \\
\text { (days) }\end{array}$ & $\begin{array}{c}\text { Average } \\
\text { vibration on } 1^{\text {st }} \\
\text { motor }(\mathrm{mm} / \mathrm{s})\end{array}$ & $\begin{array}{c}\text { Average vibration } \\
\text { on } 2^{\text {nd }} \text { motor } \\
(\mathrm{mm} / \mathrm{s})\end{array}$ & $\begin{array}{c}\text { Electricity } \\
\text { consumption } \\
(\mathrm{kWh} / \text { day })\end{array}$ & $\begin{array}{c}\text { Farine } \\
\text { production } \\
\text { (ton/day) }\end{array}$ & $\begin{array}{c}\text { SEC } \\
(\mathrm{kWh} / \text { ton })\end{array}$ \\
\hline 1 & 2.308 & 2.102 & 52,919 & 2121 & 24.95 \\
2 & 2.622 & 2.466 & 49,894 & 1969 & 25.34 \\
3 & 2.235 & 2.059 & 56,168 & 2263 & 24.82 \\
4 & 2.497 & 2.198 & 59,759 & 2399 & 24.91 \\
5 & 2.403 & 2.263 & 47,591 & 1909 & 24.93 \\
6 & 2.245 & 2.033 & 56,453 & 2269 & 24.88 \\
7 & 2.336 & 2.107 & 52,429 & 2098 & 24.99 \\
Average & 2.978 & 2.719 & 53,602 & 2147 & 24.97 \\
\hline
\end{tabular}

* Ball charge tonnage (113 tons) and production rate (101 ton/h) is kept constant and standard conditions with $8 \%$ humidity and $30 \mathrm{~mm}$ feed material size are provided during the comparison

\section{3. $\mathrm{CO}_{2}$ Emission Reduction of the Unit}

The specific energy consumption of the unit is calculated to be $25.52 \mathrm{kWh} / \mathrm{ton}$ farine. The amount of carbon dioxide emission per $\mathrm{kWh}$ of energy consumption can be taken as $940 \mathrm{~g}$ [19]. The amount of emission is found to be $23.99 \mathrm{~kg} \mathrm{CO} /$ ton farine. The annual farine production of the unit is about 649,284 ton and the corresponding carbon dioxide emission is about 16,570 tons a year. After decreasing the moisture content and the size of the feeding materials by half, the SEC of the unit is decreased by $1.29 \%$ to $25.19 \mathrm{kWh} /$ ton farine. Periodical maintenance of the unit has an important influence on both the SEC and emission values. By maintaining the periodical maintenance, the SEC of the unit is decreased by $2.16 \%$ to $24.97 \mathrm{kWh} /$ ton farine. This corresponds to a $2.16 \%$ decrease in $\mathrm{CO}_{2}$ emissions of the unit.

\section{CONCLUSIONS}

The vibration analysis and performance assessment of a raw mill indicate that the grinding process is affected by certain parameters. The main results of the study can be summarized as follows:

- The ball charge tonnage (113 tons), production capacity (101 ton/h), the humidity (8\%) and size (about $30 \mathrm{~mm}$ ) of the feeding materials are kept constant during standard production of the unit. The average vibration values of the first and second main driving motors of the unit are measured to be $2.912,2.625 \mathrm{~mm} / \mathrm{s}$ respectively. The specific energy consumption of the unit is found to be $25.52 \mathrm{kWh} /$ ton farine. Corresponding annual $\mathrm{CO}_{2}$ emission of the unit is calculated as 15,576 tons.

- The ball tonnage of the unit has been increased gradually and the vibrations on both main driving motors are measured. It is seen that, when the ball tonnage is increased by $9.7 \%$, the vibration on the first and second main driving motors have increased by $93.1 \%$ and $84.3 \%$ respectively. Additionally, the SEC of the unit has increased from 25.52 to $26.79 \mathrm{kWh} /$ ton farine.

- The size and the moisture content of the feeding materials should be as low as possible for improved performance of the process. Keeping the raw materials in a closed stock area decreases the moisture content by 30 to $40 \%$. When the moisture content of the raw materials is reduced by half, the vibration of the first and second main driving motors are decreased by $11.78 \%$ and $12.3 \%$ respectively. The average SEC of the unit has decreased from 25.52 to 25.19 $\mathrm{kWh} /$ ton farine. 
- When the periodical maintenance of the unit is strictly ensured, the vibrations on the first and second main driving motors are reduced by $20.74 \%$ and $19.92 \%$ respectively. The SEC of the unit has decreased from 25.52 to $24.97 \mathrm{kWh} /$ ton farine. The annual $\mathrm{CO}_{2}$ emission is reduced from 16,570 tons to 16,212 tons. The specific $\mathrm{CO}_{2}$ emission per ton farine produced is reduced by $2.16 \%$.

- The raw mills are big grinding facilities and there are many different parameters affecting the grinding behavior of the unit. Mill size, ball charge rate, shape, temperature and humidity of the entering raw materials, circulating load within the system, ambient air conditions, rotational speed of the mill, temporary stops for the periodical maintenance of the system, chemicals used to speed the pulverization and to eliminate the sticking problem, efficiency and performance of each machinery used, the microstructure of the raw materials and vibration characteristics of the system are some of these parameters. Further studies on the topic may involve the investigation of these parameters on the system performance and optimization of them for best operation. An economic analysis of the system can also provide significant information indicating cost allocation in the system. It is realized that, maintaining the best operational conditions for the mill is so essential to produce maximum amount of farine, to consume less energy and to decrease the emission rates of the industry.

\section{ACKNOWLEDGEMENT}

The authors acknowledge the support provided by the Scientific Research Unit (GUBAP) of the University of Gaziantep, and Erkan Demirel, Mehmet Marasli and Kursat Korkmaz from Limak Cement Group.

\section{REFERENCES}

[1] Fuersteneau DW, Abouzeid AZM. The energy efficiency of ball milling in comminution. Int. J. Miner. Process 2002; 67:161-185.

[2] Katsioti M, Tsakiridis PE, Giannatos P, Tsibouki Z, Marinos J. Characterization of various cement grinding aids and their impact on grindability and cement performance. Construction and Building Materials 2009; 23:1954-1959.

[3] Tsakalakis KG, Stamboltzis GA. Correlation of the Blaine value and the size of the cement particle size distribution. Zement-Kalk-Gips 2008; 61:60-68.

[4] Schneider M, Romer M, Tschudin M, Bolio H. Sustainable cement production present and future. Cement and Concrete Research 2011; 41:642-650.

[5] Hendrik G van Oss, Padovani AC. Cement Manufacture and the Environment Part II: Environmental Challenges and Opportunities. Journal of Industrial Ecology 2003; 7: 93-126.

[6] Worrell E, Nathan M, Price L. Potentials for energy efficiency improvement in the US cement industry. Energy 2000; 25:1189-1214.

[7] Atmaca A, Kanoglu M. Reducing Energy Consumption of a Raw Mill in Cement Industry. Energy 2012; 42:261-269.

[8] Hendriks CA, Worrell E, Jager de D, Blok K, Riemer P. Emission Reduction of Greenhouse Gases from the Cement Industry. Greenhouse gas control technologies conference paper, 2004. 
Atmaca and Atmaca / Anadolu Univ. J. of Sci. and Technology-A-Appl. Sci. and Eng. 17 (1) - 2016

[9] Schuer A, Leiman A, Ellerbock HG. Possible ways of saving energy in cement production. Cement Kalk Gips 1992; 7: 175-182.

[10] Utlu Z, Sogut Z, Hepbasli A, Oktay Z. Energy and exergy analyses of a raw mill in a cement production. Applied Thermal Engineering 2006; 26: 2479-2489.

[11] Sogut Z, Oktay Z, Hepbasli A. Investigation of effect of varying dead-state temperatures on energy and exergy efficiencies of a Raw Mill process in a cement plant. International Journal of Exergy 2009; 6: 655-670.

[12] Behera B, Mishra BK, Murty CVR. Experimental analysis of charge dynamics in tumbling mills by vibration signature technique. Minerals Engineering 2007; 20: 84-91.

[13] Kolacz, J. Measurement system of the mill charge in grinding ball mill circuits. Minerals Engineering 1997; 10: 1329-1338.

[14] Gugel K, Moon RM. Automated mill control using vibration signal processing. In: IEEE Cement Industry Technical Conference. Charleston. United States. 29 April-2 May 2007; 1: 17-25.

[15] Zeng Y, Forssberg E. Vibration characteristics in a large-scale ball mill. Scandinavian Journal of Metallurgy 1993; 22: 280-286.

[16] Huang P, Jia MP, Zhong BL. Investigation on measuring the fill level of an industrial ball mill based on the vibration characteristics of the mill shell. Minerals Engineering 2009; 22: 1200-1208.

[17] Greer WL, Johnson MD, Morton EL, Raught EC, Steuch HE, Trusty CB Jr. Portland cement. In: Buonicore AJ, Davis WT, editors. Air Pollution Engineering Manual. New York: Van Nostrand Reinhold, 1992.

[18] Tiggesbaeumker P, Williams J. Large Mills for Dry Raw Material and Clinker Grinding. IEEE, Transactions On Industry Applications 12, 1976.

[19] International Energy Agency. IEA, $\mathrm{CO}_{2}$ emissions from fuel combustion, Highlights. $\mathrm{CO}_{2}$ emissions per kWh. IEA press, 2011. pp 39-40. 